\title{
Hybrid Cultures: the Visibility of the European Invasion of Caribbean Honduras in the Sixteenth Century
}

\author{
Russell N. Sheptak and Rosemary A. Joyce
}

The Americas have been an especially important setting for the development of new understandings of the historical processes that followed colonization by Europeans, who acted as agents to introduce large populations of African origin, resulting in a colonial situation of great complexity. Originally conceived of as 'culture contact,' these discussions rapidly gained in sophistication (Lightfoot 1995; Lightfoot et al. 1998). Critiques of the idea of contact, in which two somewhat homogeneous entities collided, with the stronger exercising some sort of hegemony over the weaker, were accompanied by the development of detailed investigations of specific historical engagements (Silliman 2005, 2010). These blurred the lines between what could be considered original or novel, 'authentic' or hybrid. Models for the emergence of new populations with newly formed identities have been most completely developed under the framework of ethnogenesis (Palka 2005; Voss 2008; Weik 2004). Weik (2004, 36) defined ethnogenesis as, 'the formation of new or different sociocultural groups from the interactions, intermixtures, and antagonisms among people who took part in global processes of colonialism and slavery'.

Our research explores the colonial situation of a region centered on the city of San Pedro Sula, part of the Honduran province of the Captaincy General of Guatemala. Founded in AD 1536 as a Spanish villa (incorporated town), San Pedro flourished as the center for transmission of products of gold mines toward ports, until gold smelting was moved inland in the early 1580 s to the colonial capital city, Comayagua. From that point on, the Spanish citizenry of San Pedro Sula steadily declined.

We argue that in fact, the transformation of Honduran indigenous life preceded the formal incorporation of the province of the río Ulúa into the administrative district of San Pedro. For more than a decade before the founding of the city, indigenous towns in northern Honduras had experienced impacts of disease, raiding to capture labor for mines elsewhere in Central America, 
and military conflicts between Spanish factions that took place in and around indigenous settlements. There was also a well-developed indigenous military resistance, and it is this social movement that produced the material traces that we argue can be seen as hybrid material culture, the earliest and most transformative visible impacts of Spanish colonial engagement.

\section{$2 \quad$ Spanish Entradas in Northern Honduras}

Sheptak (2013, 68-70) summarizes the history of Spanish presence in Honduras in the early sixteenth century. This begins in $\mathbf{1 5 0 2}$ with the second voyage of Columbus, who made landfall on the mainland near what today is Trujillo (Figure 10.1). In the Bay Islands off the coast, Columbus intercepted a canoe and pressed its passengers into guiding him, before leaving them to continue their voyage (Edwards 1978). Sheptak $(2013,68)$ argues that unauthorized Spanish ships were likely setting in along the coast between 1502 and the first

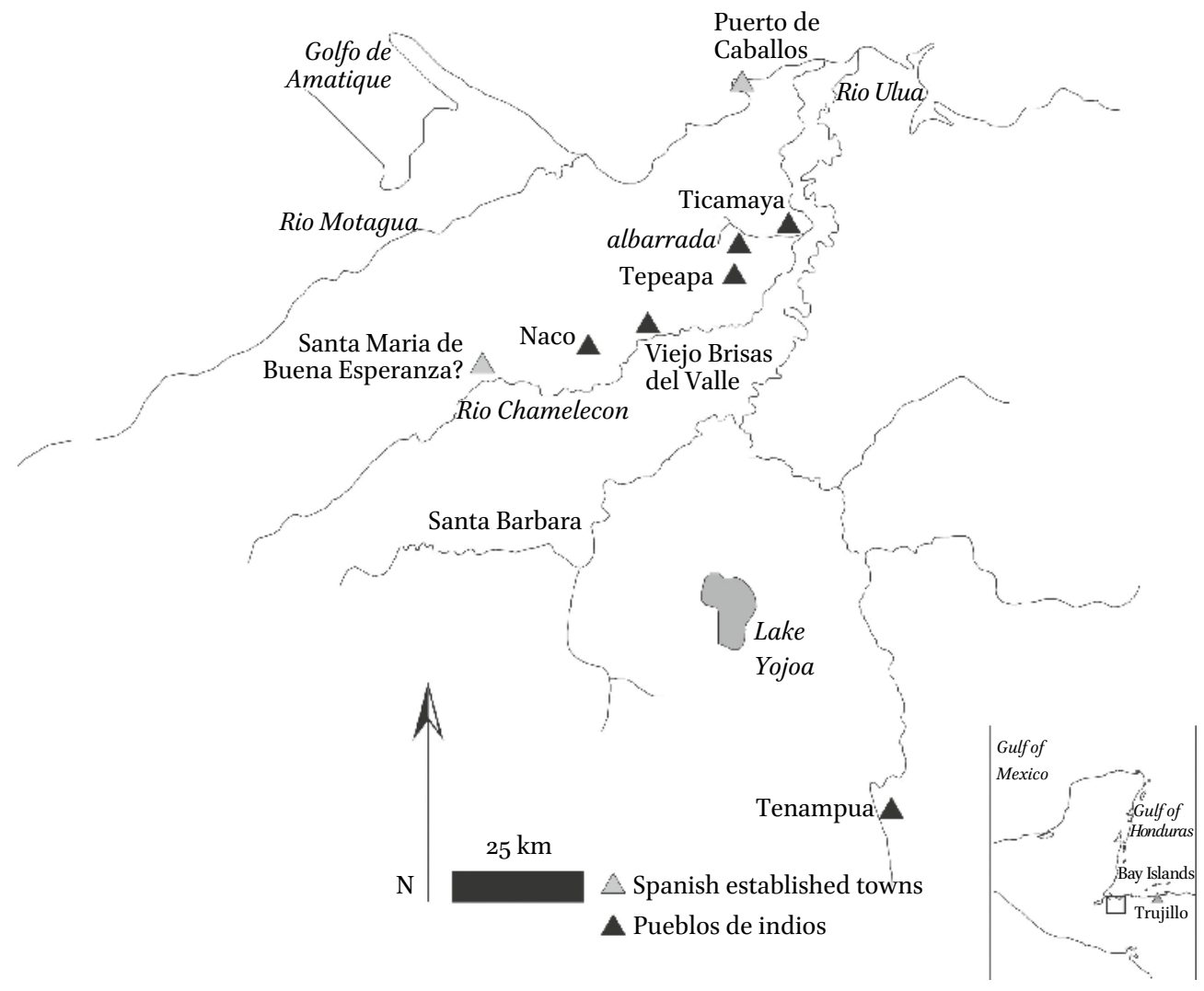

FIGURE 10.1 Map of Honduras showing locations of main sites mentioned in text 
official Spanish expedition to Honduras, which arrived in 1523 . This was the year Cristobal d'Olid and a group of 300 Spaniards, sent by Cortés from Mexico to "conquer and pacify" Honduras in his name, were shipwrecked and established their main settlement near Trujillo (Chamberlain 1953). Olid precipitated the first in a series of conflicts between would-be Spanish overlords by claiming the new colony for himself. Cortés sent a second officer, Francisco de las Casas, who was captured by Olid, and then finally followed himself, arriving in 1524 .

Olid had in the meantime established part of his forces at the indigenous town of Naco. Cortés dispatched some of his troops, including Bernal Diaz del Castillo, to this inland town, maintaining his own heading along the Caribbean coast, founding a new Spanish town, La Navidad de Nuestra Señora, near the modern location of Puerto Cortes (Cortes 1989, 1990). Another detachment of troops were sent inland from this spot, to the indigenous town, Choloma. Cortés himself took ship to Trujillo, spending about six months regaining control over the Spanish outposts in the area. Near Trujillo, Cortés describes meeting with the leaders of indigenous towns named Papayeca and Chapagua (Cortes 1989).

When Cortés departed again for Mexico in 1525 , a period of instability was begun as a series of governors of the colony were named in quick succession. By the early 1530s, the former treasurer of the colony, Andrés de Cereceda, was acting as governor. By 1533 Cereceda had relocated colonists from Trujillo to near Naco, pursuing reported gold deposits, founding a new Spanish town, Santa Maria de Buena Esperanza. In 1535, under pressure from unhappy Spanish colonists, Cereceda appealed to then-governor of Guatemala Pedro Alvarado for assistance. Alvarado received royal approval to conquer and pacify Honduras in 1532 (Chamberlain 1953). In December 1535 he arrived in Honduras, initiating military campaigns that culminated in 1536 with his attack on the indigenous resistance under a local leader named Çocamba, whose main settlement was at Ticamaya (Figure 10.1). Alvarado officially founded the city of San Pedro not far from Ticamaya, and was recognized by the remaining Spanish colonists as governor of Honduras.

\section{Excavation of Sites of Spanish Entradas}

Of the many indigenous places in the region referred to in early Spanish accounts, three have been the focus of archaeological research providing data covering the period of Spanish efforts to gain control of the territory: Naco, Ticamaya, and the Rio Claro site, identified by the excavator as the possible location of Papayeca. 


\subsection{Naco}

Excavations at Naco in the 1930 s encountered almost no apparent evidence of Spanish colonial presence (Strong et al. 1938, 32, Plate 4m). Two sherds of majolica ceramic were reported in these excavations, of unidentified type and date. More extensive excavations at Naco in the 1970s recovered no material remains attributable to early colonial Spanish presence at the site. Testing in what appears to be the same location that yielded the earlier majolica sample produced an eighteenth-century deposit with a single identified El Morro Ware sherd (Wonderley 1981, 23). The lack of European material in sixteenthcentury contexts from Naco is notable, as Spanish archival records suggest over a year of presence of troops headed by Olid, followed by residence for some months of troops accompanying Cortés, and a subsequent period of engagement culminating in the establishment of a Spanish town not far away that drew on Naco for labor and supplies for at least three years before Alvarado's campaigns were completed.

\subsection{Papayeca}

The situation is similar at the Rio Claro site (Healy 1978). Located slightly inland from the coast in the Aguan River valley, near the site of the Spanish colonial city of Trujillo, the Rio Claro site was a tightly nucleated series of earthen platforms faced in stone arranged around two plazas, surrounded by a ditch measuring 1.8 to 2.5 meters in preserved depth, with three principal entries indicated by walkways (Figure 10.2). Radiocarbon samples from the site produced dates after 1000 AD (Healy 1978, Table 1). Most samples produced calibrated dates falling between AD 1100 and 1350, and were associated with ceramics diagnostic of the Early Cocal phase (Dennett 2007). The latest sample, reported as uncalibrated $45^{\circ}+/-65 \mathrm{BP}$, would encompass the period of contact when calibrated (AD $1494+/-77)^{1}$. This sample came from an excavation in the tallest, centrally located platform in the site (Healy 1978, 20). The context of the carbon sample, and the overlying context, both included Late Cocal ceramics, the only such sherds associated with radiocarbon dates at the site, where they are otherwise found as surface materials (Dennett 2007). The charcoal dated came from a hearth defined in the second excavation level. Below this, "several" hard clay floors were noted, and a second, deeply buried concentration of burned material yielded a carbon sample dating to $905+/-65$ B P (calibrated

1 Calibrated using the Cologne Radiocarbon and Palaeoclimate Research Package Online CalPal (http://www.calpal-online.de) quickcal 2007 v1.5, with CalCurve CalPal_2007_HULU. Based on the initial ${ }_{14} \mathrm{C}$-age of $450 \pm 65 \mathrm{BP}$, results indicate a Calendric Age of $456 \pm 77 \mathrm{calBP}$, with the two-sigma (68\%) range of $378-533$ calBP, or a range of $\mathrm{AD} 1417-1572$. 


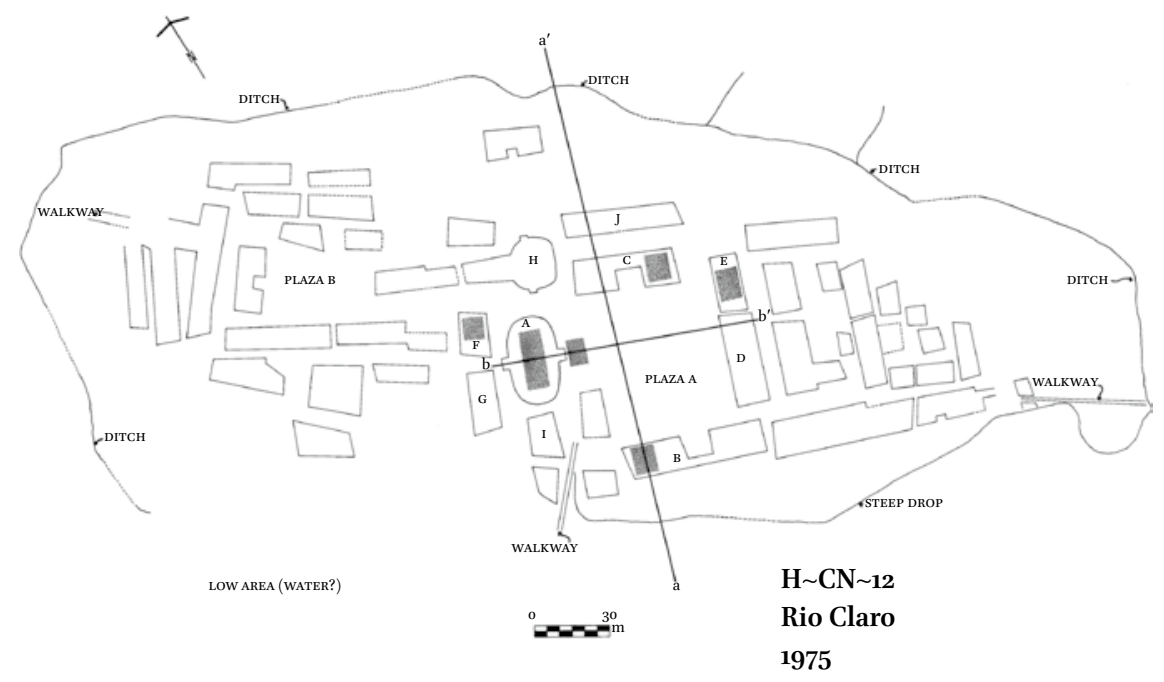

FIGURE 10.2 Plan of the Rio Claro site showing ditch surrounding compact groups of mounds (after Healy 1978, Figure 3)

as $\mathrm{AD} 1120+(-69)^{2}$. Based on its unique size, dense site plan, and late continuation of occupation, the excavator suggested that this site was possibly Papayeca, one of the places Cortés mentioned receiving visitors while he was at Trujillo (Healy 1978, 26-27).

\subsection{Ticamaya}

Ticamaya, the third site known to have been occupied during the period when Spanish troops entered Caribbean Honduras, produced the same pattern. Ticamaya is located at the ancient confluence of a former course of the Ulua River (today occupied by the Chamelecon River) and an abandoned channel of the Choloma River. Unlike the other two sites, the remains of Ticamaya are deeply buried by sediments from these two rivers. The original detection of the site was based on use of archival documents, verified by recovery of sixteenthcentury ceramics in canal backdirt.

Research at Ticamaya began with systematic auguring and magnetometer survey of part of the area to determine distribution of buried deposits, and excavation of wider units where auguring and magnetometer anomalies

2 Calibrated using the Cologne Radiocarbon and Palaeoclimate Research Package Online CalPal (http://www.calpal-online.de) quickcal 2007 v1.5, with CalCurve CalPal_2007_HULU. Based on the initial ${ }_{14} \mathrm{C}$-age of $905 \pm 65 \mathrm{BP}$, results indicate a Calendric Age of $830 \pm 69$ calBP, with the two-sigma (68\%) range of 760-899 calBP, or a range of $\mathrm{AD} 105^{-1190 .}$ 
produced evidence of buried materials in situ in five dispersed areas, within an area of continuous buried remains extending 140 by 215 meters (BlaisdellSloan 2006). Based on AMS dating of carbon samples, stratigraphic and horizontal relationships among different excavation areas, we can identify three of the five excavated areas as including features dating to the early sixteenth century (Blaisdell-Sloan 2006, 151-155).

One AMs sample came from a burned oven in Ticamaya Operation $2 \mathrm{C}$. This sample, with a reported age of $390+/-49 \mathrm{BP}$, yielded two probability peaks in calibration. One ranged from AD 1436-1530, the second AD 1538-1635. While Blaisdell-Sloan $(2006,155)$ argued for the later date span, the probability of the earlier is statistically more likely. Subsequently, Blaisdell-Sloan joined us in a re-analysis of these excavated deposits that concluded that the samples were best assigned to the earlier part of the possible range (Sheptak, Blaisdell-Sloan and Joyce 2011a).

The oven, possibly a kiln, was a one-meter diameter pit dug $50 \mathrm{~cm}$. deep, lined with burned clay (Blaisdell-Sloan 2006, 131-132, 152, 169, 228-229, 249, 254). Within the outer pit of the burned oven was a second clay structure about $50 \mathrm{~cm}$. in diameter that might have supported pots during firing. Surfaces in the adjacent excavation units yielded fragments of construction material typical of house construction (Blaisdell-Sloan 2006, 130, 182, 254). On these surfaces, a wide variety of plant remains were recovered, including coyol palm seeds, Carex sp. and Paspalum sp. (used for mats and bedding), Mamillaria sp. and lumps of tuber tissue consistent with manioc or sweet potato.

The fill inside the oven also yielded typical domestic remains, including ceramics from the late fifteenth to early sixteenth century. Also in this fill, carbonized maize seeds and tuber fragments, and bones from turtle, peccary, and white-tailed deer, reflect the same kind of domestic assemblage. Notable here was a high frequency of small obsidian dart points, which we will return to below.

A second dated carbon sample, from Ticamaya Operation $3 \mathrm{~B}$, has a reported age of $347+/-37 \mathrm{BP}$, calibrated to AD $1460-1638$. The probability distribution for this sample (Blaisdell-Sloan 2006, Figure 5.1) is slightly bimodal, with one probability peak between AD 1480 and 1530 and the other between $A D 155^{\circ}$ and 1610. Based on associated ceramics and stratigraphic relations to other excavation units, the earlier time span is more likely.

The source of this dated carbon sample was a house, Structure $3 \mathrm{~A}$, represented by a single posthole, burned mud wasp nests, and a hearth still containing a broken vessel (Blaisdell-Sloan 2006, 134-136, 249, 254-255). No wall rubble was found, suggesting the wasp's nests were attached to perishable walls made of pole and thatch, or that the structure was a roofed shelter for the hearth, with 
open walls. This house appears to have been completely burned. On the adjacent surface outside the building, more large pieces of pottery were encountered. The entire area was covered with a thin level of soil mixed with large amounts of carbon before another surface formed. The conclusion reached by Blaisdell-Sloan $(2006,152)$ was that this house suffered a major fire, quite possibly as part of the military campaign that took place at Ticamaya in 1535 .

Surfaces around the traces of Structure $3 \mathrm{~A}$ produced ceramics diagnostic of the early sixteenth century, including both utilitarian types and painted serving ware originating in Naco. Plant remains recovered from inside the building, near the hearth, included tissue from tubers, probably manioc, and Helianthus and Artemisia seeds (Blaisdell-Sloan 2006, 254-255). Bones from turtle and white-tailed deer were also recovered, reinforcing the resemblance to the area around the collapsed oven in Ticamaya Operation $2 \mathrm{C}$. Distinguishing Structure ${ }_{3} \mathrm{~A}$ from Operation 2, a piece of sheet copper and fragments of deer antler were also recovered. These may represent evidence of craft working in this area. Like Operation 2, this area also yielded a number of obsidian projectile points unifacially chipped on blades.

A third excavated area, in Ticamaya Operation $1 \mathrm{~A}$, was stratigraphically related to the same period of occupation as the two previous excavation areas. Here, a new building, Structure 1A, succeeded earlier buildings with AMS dates in the fifteenth century. Structure $1 \mathrm{~A}$ may have had unique, non-domestic use (Blaisdell-Sloan 2006, 122-124, 228, 248). It was constructed with very large (30 $\mathrm{cm}$ diameter) posts, placed in postholes unusual for being lined with plaster, perhaps implying that the posts themselves had been plastered. The immediate predecessor of Structure 1A, Structure $1 \mathrm{~B}$, had buried deposits in each corner, including tobacco seeds, ocelot and coyote teeth, and five ceramic censers (Blaisdell-Sloan 2006, 125). These features suggest this sequence of buildings could have been dedicated to ritual practices. Very few ceramics and no obsidian projectile points were found in this area. Some possible deer bone was recovered, but none of the smaller species used for food noted in other areas.

\subsection{Summary of Excavated Evidence from Contact-Period Sites}

Despite multiple reports of Spanish presence at Naco, and interactions with Ticamaya and Papayeca that included Spanish presentation of gifts, indigenous raiding and capture of Spanish prisoners, and a battle between Spanish troops and indigenous defenders, there is remarkably little in the excavated registers of these sites that directly testifies to their witnessing of these events. Only two majolica sherds at Naco have been attributed to the period, and these may actually come from a much later reoccupation of the site. However, a review of the contemporary archival documents may help us to reconsider what 
might constitute evidence of engagement with the Spanish in the material remains of sites engaged in the kinds of conflicts that colonization here involved.

\section{$4 \quad$ Fighting and Fortifications}

At Ticamaya, Blaisdell-Sloan (2006, 236-238) noted that small dart points made on obsidian blades reached their highest frequencies in the deposits assigned to the early sixteenth century. Of the total of 34 dart points, 21 (61\%) came from these contexts. This form of dart point is interpreted as intended for use in battle against human opponents, a model supported by edge-wear analysis and depositional contexts for such objects related to the violent conquest of ninth-century Aguateca, Guatemala (Aoyama 2005, 204).

Subsequently, we argued that the high frequency of dart points was evidence of a newly militarized way of life ushered in at Ticamaya when the first Spanish expeditions in the early 1520 s began to affect the Ulua River area (Sheptak et al. 2011b). The contexts with high proportions of these points also showed extensive burning of residential features (Blaisdell-Sloan 2006, 134, 154). These were particularly concentrated in Ticamaya Operation 3, while other areas sampled in Operation 1 and Operation 2 showed neither the extensive burning nor the presence of dart points.

Archival documents indicate that Ticamaya was surrounded by a palisade and ditches (Sheptak 2004). No archaeological evidence of a system of defensive features in the buried site remains was encountered by Blaisdell-Sloan (2006). Unlike the groups of sherds, lithics, and burned house construction material that she recovered through auguring, a ditch dug into the soil would not have provided a clear signature. Magnetometer survey might have provided evidence of anomalies, but the original magnetometer survey was limited to a 1900 square meter area due to malfunction of the equipment. This completed magnetometer survey was carried out in the area closest to the river bank, which archival sources indicate was left open for access from the river.

In 2008, Blaisdell-Sloan returned to the site with the intention of renewing magnetometer survey and excavations. Unfortunately, substantial construction had taken place, which limited additional areas where the method could be carried out. She added an additional 250 square meters to the surveyed area, but nothing suggestive of a ditch and palisade was recovered. While we cannot confirm the presence of a ditch and palisade described in archival documents, the compact nature of the area of buried remains is consistent with a densely nucleated site. 
While Cortés received envoys from Papayeca, neither he nor his troops described visiting the town. Based on the plan of the Rio Claro site, it appears that it too was fortified (Healy 1978, 17, 27). A ditch reaching depths of 1.8 to $2.5 \mathrm{~m}$ is preserved around most of the compact cluster of buildings. In the one area where it is not found, evidence suggests there was a body of water, corresponding to the description of Ticamaya with its main entry from the river. The measured area of the Rio Claro site, $450 \times 190 \mathrm{~m}$, is slightly larger than the known extent of Ticamaya, 140 by $215 \mathrm{~m}$.

At 8.55 hectares, the Rio Claro site, while larger than 3.01 hectare defined area of Ticamaya, is still much smaller than Naco, which is given as occupying 90 hectares (Henderson et al. 1979, 172). This difference alone suggests that Naco, unlike Ticamaya and the Rio Claro site, was not situated for defense. In addition, the Spanish word used in sixteenth-century documents describing Ticamaya and its allied towns, albarrada, occurs in Bernal Diaz del Castillo's account of cities in Mexico (1980), but is not used by him in his description of Naco.

Comparing the documented histories of relations between each of these towns and the early Spanish expeditions, Naco is distinguished from Papayeca and Ticamaya by a history of welcoming visitors. In contrast, the leaders of Papayeca, although initially willing to exchange gifts with Cortés, ended up leading military resistance against the Spanish colony, and were captured by Cortés (Cortes 1989).

Ticamaya has the most abundantly detailed record of military conflict with the Spanish forces (Sheptak 2004). In 1536, Pedro Alvarado described the town as the seat of a "señor" (lord) whose name we transcribe as Çocamba (AGI Patronato 20 N. 4, R. 6). Alvarado noted that "by visiting" (por visitación) he knew that Ticamaya had around eighty men. He identified it as having "some small towns subject to them" (unos pueblos pequeños a ellos sujeto) with fifteen, eight, and six houses, respectively.

Letters from Andres de Cereceda, governor of the Spanish colony in 1535 (AGI Guatemala 39 R. 2 N. 4), and Diego Garcia de Celis, treasurer, in 1534 (AGI Guatemala 49 N. 9) provide more details of hostilities between Ticamaya and its allies and the Spanish colonists. These letters attribute military campaigns resulting in the death or capture of the residents of a settlement that Cortés had established in 1525 near the location of modern Puerto Cortes (Puerto Caballos) to the leader of Ticamaya.

Cereceda described the sacking of Puerto Caballos sometime before 1533, saying that Çocamba had killed ten men of the settlement and captured and kept a Spanish woman prisoner (AGI Guatemala 39 R. 2 N. 4). He gave this as an excuse for his own aggression against outlying settlements that were 
subordinate to Ticamaya during a march from Trujillo to the Naco valley in 1533, writing that

... on the Rio Balahama, where our path went, we found a palisade (albarrada) of those that I have written about to your majesty, that the indians of that region and of the Rio Ulua make for their stronghold.

AGI Guatemala 39 R. 2 N. 4 1/1

Cereceda nonetheless decided to camp out within the vicinity of this palisade, and then reports that:

... a little after midnight ... certain indians came from down river in canoes with a great shouting and throwing arrows (tirando flechas) that fell on our camp that injured some of the indians in servitude that we had with us and horses.

AGI Guatemala 39 R. 2 N. 4

With this attack as his pretext, Cereceda says "I went over the palisade with fifty men," putting the indigenous troops to flight, and taking two leaders (principales) prisoner. He then sent these two prisoners to "the cacique Çocamba of the Ulua River at his albarrada which was two leagues from there" (AGI Guatemala 39 R. 2 N. 4).

The treasurer De Celis provides his own account of the same incident:

... we went to block a town subject to the greatest cacique that they have in all that governance as they say, who the indians call the great merchant Çocamba, and so we took fifty prisoners two leagues from his house (casa) ... they informed the governor that this Çocamba is very fortified with with heavy palisades (albarradas) of thick wood and that they had made a large quantity of pits covered with bark from them ... many people say that his albarrada is very fortified, of seven or eight rows of very rough wood with their towers and openings, and that it would be a very difficult thing to enter because there is no entry except over the river on which this is located on the barranca of the river.

AGI Guatemala 49 N. 9

Cereceda noted that previous to the arrival of Alvarado, another Spanish troop from Guatemala had gone to try to punish the deaths of the people of Puerto Caballos, to "break the palisaded fortress of Çocamba and others of the caciques of that river in which they were making forts" (a romper el albarrada de 
Çocambay otras de caciques de aquel rio en que se hacia fuertes; AGI Guatemala 39 R. 2 N. 4). This passage gives a sense that the building of fortifications was an ongoing process along the Ulua River.

It appears that Ticamaya headed an organized resistance involving multiple fortified towns that had been underway for a decade when Alvarado undertook the campaign that defeated Ticamaya in 1536 and resulted in the capture of its leader, Çocamba. The events of this final battle were described in another letter by Cereceda, written in 1536 . Although the document has been worn along the right edge, enough remained for us to produce a transcription. It describes the indigenous warriors attempting to flee on the river, but being caught by Alvarado using a very large canoe with artillery in the prow to attack Ticamaya from the river, preventing "the entry or exit from the albarrada to the river" (AG I Guatemala 39 R. 2 N. 6). Witnessing the deaths of his people under fire, the leader of Ticamaya surrendered.

\section{Fortifications as Hybrid Tactics}

Reading the archival record, it is clear that early sixteenth-century towns in the Ulua valley were fortified places. The Rio Claro site, identified as historic Papayeca, shows us what the remains of such a fortified place would have looked like if all the features were still visible on the surface, instead of buried by river sediment as is the case with Ticamaya. Yet in the Ulua and the Aguan valleys, there is no previous history of fortified sites. Nor are fortifications a practice in other parts of Honduras during the early sixteenth century: Naco appears to have been composed of a dispersed group of structures along the Naco River. Another, even larger fifteenth- to sixteenth-century site, Viejo Brisas del Valle, located along the Chamelecon River between the Naco and Ulua Valleys, has no sign of fortifications or even close spacing of buildings that might suggest there had once been perishable defensive walls (Neff et al. 1990).

One much earlier Honduran site from far inland is noted for its defensive walls. This site, Tenampua, occupies a mesa overlooking the Comayagua valley (Dixon 1989, 264-266). Between AD 900-1000, Tenampua grew to contain more than 400 buildings distributed in clusters across the mesa. The approach to the site is protected by a system of stone walls (Dixon 1987). The main wall was described in an early report as 225 meters long, up to 3 meters tall, and 8 meters thick, composed of rocks 45 to $60 \mathrm{~cm}$ in diameter joined in a mud plaster (Popenoe 1935, 562). Nothing about the walls of Tenampua matches the archaeological features from the Rio Claro site, or the description of the Ticamaya palisade. 
Farther afield, walled precincts protecting the residences of the wealthy nobility are described for the northern Yucatan lowlands (Cortes Rincon 2007, 179-180). These are said to have been added to sites originally having open plans, in response to military threats, some described as "hastily" built. They have thick stone walls which could have supported palisades but lack the ditches, towers, and slit windows for shooting described for Ticamaya or known from the Rio Claro site. A review of lowland Maya sites with fortifications (Webster 1976, 368) concluded that earthen ditch and embankment defensive walls were products of early Classic (or even earlier occupation), and that the norm for the period immediately before the Spanish entry into the area was dry-laid stone walls, not unlike the one described for Tenampua.

While not the kind of material marker of initial Spanish contact that archaeologists have traditionally expected, we argue that the enclosure of late sites like Ticamaya and Rio Claro by ditch and palisade defensive walls should be seen as an innovative product of the engagement of indigenous Honduran peoples with Spanish troops seeking to invade and control their communities. From reports of two battles, described above, in which Spanish troops attacked such albarradas at Ticamaya and a nearby outlying site, we can see that these fortifications were not able to indefinitely repel either a larger number of troops willing to storm the walls, or (in the case of Ticamaya) an attack by boats carrying ordinance. Yet the Spanish sources are also clear that Hondurans employing such fortifications were able to ward off attempts at colonization for a decade.

Part of a shift toward militarization also seen at Ticamaya in the increase in obsidian points appropriate for use against human targets (Sheptak et al. 2011a), the investment in fortification at this site and others it organized in resistance to colonization is presented in documentary sources as an ongoing process. This process itself was, we have suggested, a product of cultural hybridity in the first decades of the sixteenth century. The same documents that describe Ticamaya and its defeat also describe the death in the final battle there of a shipwrecked Spanish sailor turned member of the indigenous military. In his 1536 letter describing the defeat of Ticamaya, Cereceda adds that after he surrendered,

... the cacique Çocamba said that in the battle inside the albarrada the previous day that, hit by fire from an arquebus, there had died a Spanish Christian named Gonzalo Aroca who is the one who walked among the indians in the province of Yucatan for twenty years and more that it is he that they say destroyed the Adelantado Montejo and how that having depopulated the Christians there he came to aid those here with a fleet of fifty canoes to kill those of us that were here.

AGI Guatemala 39 R. 2 N. 6 
Gonzalo Aroca is more commonly identified as Gonzalo Guerrero, shipwrecked in Yucatan before 1520, who refused an offer from Cortés to rejoin the Spanish saying he was married and had children, and had pierced his ears and tattooed his body. We view Gonzalo as a cultural mediator who may well have been critical in helping shape new emergent tactics of military defense against an enemy he knew well, having been part of it. The development of ditch and palisade defensive works in Honduras in sites that continued to resist Spanish invasion long after Naco had become a support for the new colony is a sign of contact, not in the form of imported European goods (which are rare in the country until the late eighteenth century), but in the form of new ways of living to adjust to new and deadly threats.

We have argued that we need to question what material registers might indicate "Spanish" or "colonization" in terms of emergent practices in relevant times for each place. The use of chronometric methods to establish dating is critical, as there can be no reliance on novel introduced material culture to identify the chronological placement of sites if the residents do not have access to, prize, or desire these things.

We have previously argued that expectations about how material practices would change during initial engagement of indigenous societies with Europeans and Africans in Honduras have impeded understanding colonial material registers (Joyce and Sheptak 2014). For example, research in Santa Barbara, Honduras, southwest of the Ulua valley, documented a series of colonial churches in towns where residential remains, from houses to pottery, were indistinguishable from those of the period before Spanish missionization (Weeks 1997; Weeks and Black 1991; Weeks et al. 1987).

We suggest that Michel de Certeau's (1984) concept of everyday practices as "tactics" helps anticipate the improvisational and emergent properties of new ways of doing things that may be the most common material sign of Europeanindigenous encounters. Tactics, we note,

... are not extraordinary, but ordinary; they are the continuing ways that human subjects occupy social landscapes that they do not entirely control. Tactics can be conceived of as the "appropriation" of what is offered in places like the colonial settings we examine, exceeding the intentions of those who seek control, seizing the moment for one's pragmatic ends.

SHEPTAK, et al. 2011b, 149-150 
The construction of fortifications in anticipation of attacks by Spanish troops was tactical adaptation during a period of challenges to the existing political order. It cannot be easily identified as either a wholly indigenous or introduced trait. The obsidian assemblage from Ticamaya provides a second illustration of the emergent and hybrid nature of material evidence of these relations. The kind of obsidian dart points made from blades that reached their peak frequency at a moment when a sector of the settlement was burned have been identified in Belize as products made for the purpose of military defense against the invading Spanish there as well (Simmons 1995). A completely indigenous material and a form unknown in Europe, it is the intensified production and use of these blades that marks the early period of invasion and conflict.

We suggest that the situation that arises is productively viewed using concepts of hybridity and ethnogenesis. Ethnogenesis places an emphasis on what emerges, not what preceded. As Barbara Voss (2008) demonstrated in her study of the new 'Californio' identity shaped at the Spanish Presidio of San Francisco, what emerges cannot be separated into component parts. Our emphasis on the emergence of new forms through tactical engagement in material practices aligns us with the tradition represented by William Hanks (2010, 93-94), who sees the attempt 'to divide an indigenous inside from a Hispanicized exterior' as 'sundering the person into two parts,' possible only if each belongs to a distinct social field. In the beginning of the Honduran colony, what we see is the taking up of positions in fields that linked people coming from different spaces in practices that we can say are innovative indigenous works, reframings of Spanish renegade knowledge, and repurposing of traditional techniques of construction all at the same time.

\section{Archival Documents}

\section{Abbreviations used:}

AGCA Archivo General de Centroamerica, Guatemala City, Guatemala

AG I Archivo General de Indias, Sevilla, Spain

1534 "Cartas de oficiales reales de Honduras: Diego Garcia de Celis, Puerto de Caballos 6/20/1534" AGI Guatemala 49 N. 9

1535 "Cartas de gobernadores: Andres de Cereceda, Buena Esperanza 8/31/ 1535" AG I Guatemala 39 R. 2 N. 4

1536 "Cartas de gobernadores: Andres de Cereceda, Puerto de Caballos 8/ 14/1536" AGI Guatemala 39 R. 2 N. 6 


\section{References}

Aoyama, Kazuo. 2005. "Classic Maya Warefare and Weapons; Spear, Dart, and Arrow points of Aguateca and Copan." Ancient Mesoamerica 16 (2): 291-304.

Blaisdell-Sloan, Kira. 2006. An Archaeology of Place and Self: The Pueblo de Indios of Ticamaya, Honduras (1300-180o AD). Ann Arbor: The University of Michigan Press.

Certeau, Michel de. 1984. "Making Do: Uses and Tactics." In The Practice of Everyday Life, translated by Steven F. Rendall, 29-42. Berkeley: University of California Press.

Chamberlain, Robert S. 1953. "The Conquest and Colonization of Honduras: 1502-1550." Carnegie Institution of Washington Publication 598. Washington, D.C.: Carnegie Institution of Washington.

Cortes, Hernán. 1989. Letters from Mexico. Translated and edited by Anthony R. Pagden New Haven: Yale University Press.

Cortes, Hernán. 199o. "Ordenanzas para las Villas de La Navidad y Trujillo en Honduras." In Documentos Cortesianos, Volume 1, 1518-1528, edited by José Luis Martinez, 347-351. Mexico: Universidad Nacional Autonoma de Mexico, Fondo de Cultura Economica.

Cortes Rincon, Marisol. 2007. “A Comparative Study of Fortification Developments Throughout the Maya Region and Implications for Warefare." PhD diss., University of Texas, Austin.

Dennett, Carrie L. 2007. "The Río Claro Site (AD 1000-1530), Northeast Honduras: A Ceramic Classification and Examination of External Connections." Master thesis, Trent University.

Diaz de Castillo, Bernal. 1980. Historia verdadera de la Conquista de la Nueva España. Mexico: Editorial Porrua.

Dixon, Boyd. 1987. "Conflict along the Southeast Mesoamerican Periphery: A Defensive Wall System at the Site of Tenampa." In Interaction on the southeast Mesoamerican Frontier, Part 1, edited by Eugenia J. Robinson, 142-153. Oxford: British Archaeological Reports, International Series, 327.

Dixon, Boyd.1989. "A Preliminary Settlement Pattern Study of a Prehistoric Cultural Corridor: The Comayagua Valley, Honduras." Journal of Field Archaeology 16 (3):257-271.

Edwards, Clinton R. 1978. "Precolumbian Maratime Trade in Mesoamerica." In Mesoamerican Communication Routes and Culture Contacts, edited by Thomas A. Lee and Carlos Navarrete, 199-210. Papers of the New World Archaeological Foundation 40. Orinda: New World Archaeological Foundation.

Hanks, William F. 2010. Converting Words: Maya in the Age of the Cross. Berkeley: University of California Press.

Healy, Paul H. 1978. "Excavations at Rio Claro, Northeastern Honduras: Preliminary Report." Journal of Field Archaeology 5 (1): 15-28. 
Henderson, John, Ilene Sterns, Anthony Wonderley, and Patricia A. Urban. 1979. "Archaeological Investigations in the Valle de Naco, Northwestern Honduras: A Preliminary Report." Journal of Field Archaeology 6 (2): 169-192.

Joyce, Rosemary A. and Russell N. Sheptak. 2014. "History Interrupted: Doing 'Historical Archaeology' in Central America." In The Death of Prehistory, edited by Peter R. Schmidt and Stephen A. Mrozowski, 161-182. Oxford: Oxford University Press.

Lightfoot, Kent G. 1995. "Culture Contact Studies: Redefining the Relationship Between Prehistoric and Historical Archaeology." American Antiquity 60 (2): 199-217.

Lightfoot, Kent G., Antoinette Martinez, and Ann M. Schiff. 1998. "Daily Practice and Material Culture in Pluralistic Social Settings: An Archaeological Study of Culture Change and Persistence from Fort Ross, California." American Antiquity 63 (2): 199-222.

Neff, Hector, Patricia Urban, and Edward Schortman. 1990. "Late Prehistoric Developments in Northwestern Honduras: Preliminary Report on the 1990 Investigation at Viejo Brisas del Valle." Tegucigalpa, Honduras: Instituto Hondureño de Antropología e Historia. Report in the Archives of the Institute.

Palka, Joel W. 2005. Unconquered Lacandon Maya: Ethnohistory and Archaeology of Indigenous Culture Change. Gainesville: University Press of Florida.

Popenoe, Dorothy H. 1935. “The Ruins of Tenampua." Smithsonian Institution, Annual Report, 559-572. Washington, D.C.: Smithsonian Institution.

Sheptak, Russell N. 2004. "Noticias de un cacique indígena de la época colonial: Una contribución a la historia colonias de Honduras." Paper presented at the VII Congreso Centroamericano de Historia, Tegucigalpa, Honduras, 19-23July.

Sheptak, Russell N. 2013. "Colonial Masca in Motion: Tactics of Persistence of a Honduran Indigenous Community." PhD diss., Faculty of Archaeology, Leiden University.

Sheptak, Russell N., Kira Blaisdell-Sloan, and Rosemary A. Joyce. 2011a. "In-Between People in Colonial Honduras: Reworking Sexualities at Ticamaya." In The Archaeology of Colonialism: Intimate Encounters and Sexual Effects, edited by Barbara L. Voss and Eleanor Casella, 156-172. Cambridge: Cambridge University Press.

Sheptak, Russell N., Rosemary A. Joyce, and Kira Blaisdell-Sloan. 2011b. "Pragmatic Choices, Colonial Lives: Resistance, Ambivalence, and Appropriation in Northern Honduras." In Enduring Conquests, edited by Matthew Liebmann and Melissa S. Murphy, 149-172. Santa Fe: School for Advanced Research.

Silliman, Stephen W. 2005. "Culture Contact or Colonialism? Challenges in the Archaeology of Native North America." American Antiquity 70 (1):55-74.

Silliman, Stephen W. 2010. "Indigenous Traces in Colonial Spaces: Archaeologies of Ambiguity, Origins, and Practice." Journal of Social Archaeology 10 (1): 28-58.

Simmons, Scott E. 1995. "Maya Resistance, Maya Resolve: The Tools of Autonomy from Tipu, Belize." Ancient Mesoamerica 6 (2): 135-146. 
Strong, William D., Alfred V. Kidder, and Anthony J.D. Paul. 1938. Preliminary Report on the Smithsonian Institution-Harvard University Archaeological Expedition to Northwestern Honduras 1936. Washington, D.C.: Smithsonian Institution.

Voss, Barbara L. 2008. The Archaeology of Ethnogenesis: Race and Sexuality in Colonial San Francisco. Berkeley: University of California Press.

Webster, David. 1976. "Lowland Maya Fortification." Proceedings of the American Philosophical Society $120(5): 361-371$.

Weeks, John M. 1997. "The Mercedarian Mission System in Santa Bárbara de Tencoa, Honduras." In Approaches to the Historical Archaeology of Mexico, Central and South America, edited by Janine Gasco, Greg C. Smith, and Patricia Fournier Garcia, 91-100. Los Angeles: The Institute of Archaeology, UCLA.

Weeks, John M. and Nancy J. Black. 1991. "Mercedarian Missionaries and the Transformation of Lenca Society in Western Honduras, 1550-170o." In Columbian Consequences, Vol. 3: The Spanish Borderlands in Pan American Perspective, edited by David H. Thomas, 245-261. Washington, D.C.: Smithsonian Institution Press.

Weeks, John M., Nancy J. Black, and J. Stuart Speaker. 1987. "From Prehistory to History in western Honduras: The Care Lenca in the colonial province of Tencoa." In Interaction on the Southeast Mesoamerican Frontier, Part 1, edited by James A. Robinson, 65-94. Oxford: British Archaeological Reports, International Series 327.

Weik, Terrance. 2004. "Archaeology of the African Diaspora in Latin America." Historical Archaeology 38 (1): 32-49.

Wonderley, Anthony W. 1981. Late Postclassic Excavations at Naco, Honduras. Latin American Studies Program Dissertation Series No. 86. Ithaca, NY: Latin American Studies Program, Cornell University. 